\title{
PC-PNDT act: perspectives of medical undergraduates in a Sub-Himalayan state
}

\author{
Rajiv Kumar Gupta ${ }^{1 *}$, Parveen Singh ${ }^{1}$, Shahid Hussain ${ }^{2}$, Rashmi Kumari', \\ Bhavna Langer ${ }^{1}$, Riya Gupta ${ }^{3}$
}

\author{
${ }^{1}$ Department of Community Medicine, Government Medical College, Jammu, India \\ ${ }^{2}$ Directorate of Health Services, Jammu, India \\ ${ }^{3}$ Acharya Shri Chander College of Medical Sciences and Hospital, Sidhra, Jammu, India
}

Received: 02 June 2017

Accepted: 29 June 2017

\section{*Correspondence:}

Dr. Rajiv Kumar Gupta,

E-mail: rajivguptagmc@rediffmail.com

Copyright: (c) the author(s), publisher and licensee Medip Academy. This is an open-access article distributed under the terms of the Creative Commons Attribution Non-Commercial License, which permits unrestricted non-commercial use, distribution, and reproduction in any medium, provided the original work is properly cited.

\section{ABSTRACT}

Background: Sex selective abortions have grossly distorted the child sex ratio in India. Role of medical technology in declining sex ratio at birth cannot be undermined. To combat this social evil, PC-PNDT (Pre-conception Prenatal Diagnostic Test) was promulgated in 2003 by Government of India. Enhancing the knowledge of medical fraternity with focus on undergraduate students can imbibe an enduring commitment towards this predicament

Methods: The present cross-sectional study was conducted in Government Medical College of Jammu. Students of $1^{\text {st }}$ year MBBS of Batch 2016-2017 were administered the pre-designed and pretested questionnaire. Information was collected regarding sex determination as well as PC-PNDT Act.

Results: $80 \%$ respondents knew about the declining sex ratio and 95\% knew that sex determination is possible during pregnancy. Only $24.29 \%$ had heard about PC-PNDT Act although $95 \%$ knew that prenatal sex determination is punishable. Higher proportions of female respondents were aware of both fine and imprisonment as punishment under the act. $(\mathrm{p}<0.05)$. Regarding technique used for sex determination, males had better knowledge about ultrasonography than their female counterparts $(\mathrm{p}<0.05)$. More females would like to have male child as preferred first child $(\mathrm{p}<0.05)$ and $87.14 \%$ of respondents preferred that sex determination be punished more vigorously.

Conclusions: Awareness about some of the parameters about PC-PNDT Act among the medical undergraduates was poor and it would be pertinent to hold more educational sessions for them.

Keywords: Medical undergraduates, PC-PNDT, Sex determination

\section{INTRODUCTION}

Sex ratio is an important social indicator of prevailing equity between males and females in the society. Changes in sex ratio reflect underlying socioeconomic and cultural patterns. Globally, the sex ratio is calculated as the number of males per one hundred females in a population while in India, it is defined as number of females per 1000 males. ${ }^{1,2}$ India is among those countries in the world which haven't shown any improvement in the sex ratio over the years and sex ratio has been on decline since $1901 .^{3}$

The decline in sex ratio is manmade and has been ascribed to various factors including increased sex selective female abortions as well as female foeticide. Birth of female child is perceived as a curse with economic and social liability. ${ }^{4}$ The desire for a male child is so intense that couples go for repeated pregnancies and even opt for sex selective abortions. Main reason for 
female foeticide is based on a common perception that the female child is an economic burden on the family due to dowry problems and vulnerability of them for sexual harassment, whereas males carry out family business and supports parents at a later age. ${ }^{5}$ Reports from various quarters have indicated that fear of violence may be the cause for female foeticide. Also, the women who give birth to daughters face much more domestic violence which makes them complicit in getting rid of girl child.

In order to curb sex selective abortions, the government of India introduced the Prenatal Diagnostic Techniques Act (PNDT) that was later amended as Pre-conception and Pre-natal Diagnostic Techniques Act (PCPNDT). ${ }^{6}$ The objective of the act was to prevent the misuse of diagnostic techniques in sex selection and sex selective abortions. To create awareness in the public, mass media was used extensively. Even help from spiritual and religious leaders was sought in this regard. But apparently, these measures failed to achieve the desired results with no improvement in the sex ratio. ${ }^{7}$

When the couples intend to go for sex selection, the medical/nursing community are usually the first contact. In this context, misuse of technology for this social evil is a matter of grave concern for the society. It is important to sensitise undergraduate medical students who as future health care providers to not indulge in such unethical practices and in fact may act as game changers in this context. Hence the present study was carried out among medical undergraduates to assess their perspectives regarding pre-conception prenatal diagnostic techniques act.

\section{METHODS}

The present cross-sectional study was carried out among the first-year medical students in a government medical college in North India. The study was carried out in the month of March 2017. There are 150 students in the first year MBBS class.

A questionnaire was prepared to assess the knowledge and attitude regarding the PC-PNDT Act among the medical students by the public health experts of the same medical college. The initial workup was conducted by the public health experts with the aim to develop a series of questions for the questionnaire to be administered to the medical students. A question was accepted for inclusion in the questionnaire only when agreed upon by all the members of the group. Thus, a predesigned, pretested and self-administered multiple response questionnaire was administered to the students. The questionnaire consisted of 17 questions and was divided into 2 parts; (1) knowledge part which included question number 1- 12 and (2) attitude component; question number 13-17. The details of the questionnaire are provided in the results section. The questionnaire thus prepared was pilot tested on a group of 25 medical students of second year MBBS who were not part of study sample. All the first-year medical students were informed about the objectives of the study and assured that the information collected would be treated as confidential and used for research purpose only. Only those students who gave a verbal informed consent were administered the questionnaire. The questionnaire was administered to the students in their class rooms. The students were adequately spaced during the questionnaire administration to avoid any communication. Due clarification was provided to students who asked for it regarding any of the item in the questionnaire. No names or other identifying information were included except the gender, age and religion on the self-administered questionnaire to ensure anonymity.

The results obtained were analysed and data presented as proportions. Pearson's Chi square test was used to find out the association and two tailed $\mathrm{p}$ value $<0.05$ was considered significant.

\section{RESULTS}

In all, 140 first year MBBS students participated in the study. $52.14 \%$ of them were females, $77.14 \%$ were aged $>18$ years and majority $(53.57 \%)$ were Hindu by religion. (Table 1).

Table 1: Socio-demographic variables of the respondents $(n=140)$.

\begin{tabular}{|c|c|}
\hline Socio- demographic variables & Frequency (\%) \\
\hline \multicolumn{2}{|l|}{ Sex } \\
\hline Male & $67(47.86)$ \\
\hline Female & $73(52.14)$ \\
\hline \multicolumn{2}{|l|}{ Age group } \\
\hline$<18$ years & $32(22.86)$ \\
\hline$>18$ years & $108(77.14)$ \\
\hline \multicolumn{2}{|l|}{ Religion } \\
\hline Hindu & $75(53.57)$ \\
\hline Muslim & $57(40.71)$ \\
\hline Others & $08(5.71)$ \\
\hline
\end{tabular}

Awareness about declining sex ratio was more in females $(84.93 \%)$ vis a vis males $(76.12 \%)$ and mass media was the main source of information. Although majority of the students knew that sex determination was possible during pregnancy, yet $66.6 \%$ of males and $56.3 \%$ of females reported ultrasonography and amniocentesis respectively as the most common techniques ( $\mathrm{p}<0.05)$. Only $28.36 \%$ of male students and $20.55 \%$ of female students had heard of PC-PNDT Act and about three fourth of both sexes were able to write its full form.

Majority of the respondents were aware that prenatal sex determination is punishable and there is fine as well as imprisonment under the act. Higher proportion of males were aware about the notice to be displayed outside the USG clinic and about the declaration by pregnant women before undergoing ultrasonography and this difference was statistically highly significant $(\mathrm{p}<0.00)$ (Table 2$)$. 
Table 2: Awareness regarding sex determination among respondents $(n=140)$.

\begin{tabular}{|c|c|c|c|c|c|}
\hline Question & Response & Male $(n=67)$ & Female $(n=73)$ & Total $(n=140)$ & $P$ value \\
\hline \multirow{2}{*}{$\begin{array}{l}\text { Do you know sex ratio is } \\
\text { declining in India }\end{array}$} & Yes & $51(76.12)$ & $62(84.93)$ & 113 (80.71) & \multirow{2}{*}{0.18} \\
\hline & No & $16(23.88)$ & $11(15.07)$ & $27(19.29)$ & \\
\hline \multirow{4}{*}{ If yes, source of information } & Mass media & $28(54.90)$ & $45(72.58)$ & $73(64.60)$ & \multirow{4}{*}{0.20} \\
\hline & Family/ friends & $08(15.69)$ & $05(8.06)$ & $13(11.50)$ & \\
\hline & Teachers & $11(21.56)$ & 07 (11.29) & $18(15.93)$ & \\
\hline & Any other & $04(7.84)$ & $05(8.06)$ & $09(7.96)$ & \\
\hline \multirow{2}{*}{$\begin{array}{l}\text { Is sex determination possible } \\
\text { during pregnancy }\end{array}$} & Yes & $63(94.03)$ & $71(97.26)$ & 134 (95.71) & \multirow{2}{*}{0.34} \\
\hline & No & $4(5.97)$ & $2(2.74)$ & $6(4.29)$ & \\
\hline \multirow{3}{*}{$\begin{array}{l}\text { If yes, name the most common } \\
\text { technique used }\end{array}$} & USG & $42(66.67)$ & $25(35.21)$ & $67(50.00)$ & \multirow{3}{*}{0.00} \\
\hline & Amniocentesis & $19(30.16)$ & $40(56.34)$ & $59(44.03)$ & \\
\hline & Don't know & $02(3.17)$ & $06(8.45)$ & $8(5.97)$ & \\
\hline \multirow{2}{*}{$\begin{array}{l}\text { Have you heard of PCPNDT } \\
\text { act }\end{array}$} & Yes & $19(28.36)$ & $15(20.55)$ & $34(24.29)$ & \multirow{2}{*}{0.28} \\
\hline & No & 48 (71.64) & $58(79.45)$ & $106(75.71)$ & \\
\hline \multirow{2}{*}{ If yes, write its full form } & Correct & $14(73.68)$ & $11(73.33)$ & $25(73.53)$ & \multirow{2}{*}{0.98} \\
\hline & Incorrect & $05(26.32)$ & $04(26.67)$ & 09 (26.47) & \\
\hline \multirow{2}{*}{$\begin{array}{l}\text { Is prenatal sex determination } \\
\text { punishable offence }\end{array}$} & Yes & $65(97.01)$ & $68(93.15)$ & $133(95.00)$ & \multirow{2}{*}{0.29} \\
\hline & No & $2(2.99)$ & $5(6.85)$ & $07(5.00)$ & \\
\hline \multirow{3}{*}{$\begin{array}{l}\text { If yes, what is the punishment } \\
\text { under the act }\end{array}$} & Fine & $16(24.62)$ & $06(8.82)$ & $22(16.54)$ & \multirow{3}{*}{0.04} \\
\hline & Imprisonment & $02(3.07)$ & $04(5.88)$ & $06(4.51)$ & \\
\hline & Both & $47(72.31)$ & $58(85.29)$ & $105(78.95)$ & \\
\hline \multirow{2}{*}{$\begin{array}{l}\text { Is registration of USG machine } \\
\text { mandatory }\end{array}$} & Yes & $62(92.54)$ & $67(91.78)$ & $129(92.14)$ & \multirow{2}{*}{0.86} \\
\hline & No & $05(7.46)$ & $06(8.22)$ & $11(7.86)$ & \\
\hline \multirow{2}{*}{$\begin{array}{l}\text { Whether any notice is to be } \\
\text { displayed outside the clinic }\end{array}$} & Yes & $59(88.06)$ & $44(60.27)$ & $103(73.57)$ & \multirow{2}{*}{0.00} \\
\hline & No & $08(11.94)$ & $29(39.73)$ & 37 (26.43) & \\
\hline \multirow{2}{*}{$\begin{array}{l}\text { Do u know about any } \\
\text { declaration by pregnant lady } \\
\text { before undergoing USG }\end{array}$} & Yes & $45(67.16)$ & $27(36.99)$ & $72(51.43)$ & \multirow[b]{2}{*}{0.00} \\
\hline & No & $22(32.84)$ & $46(63.01)$ & $68(48.57)$ & \\
\hline \multirow{4}{*}{$\begin{array}{l}\text { Who are the persons held } \\
\text { responsible for sex } \\
\text { determination under the } \\
\text { PCPNDT Act }\end{array}$} & Only doctors & $12(17.91)$ & $09(12.32)$ & $21(15.00)$ & \multirow{4}{*}{0.58} \\
\hline & $\begin{array}{l}\text { Only pregnant } \\
\text { female }\end{array}$ & $01(1.49)$ & $03(4.11)$ & $04(2.86)$ & \\
\hline & $\begin{array}{l}\text { Only } \\
\text { relatives/attendants }\end{array}$ & $03(4.48)$ & $02(2.75)$ & $05(3.57)$ & \\
\hline & $\begin{array}{l}\text { Doctor, pregnant } \\
\text { female and } \\
\text { relatives/ attendants }\end{array}$ & $51(76.12)$ & $59(80.82)$ & $110(78.57)$ & \\
\hline
\end{tabular}

When attitude of the respondents was analysed, higher proportion of females were of the opinion that sex determination be punished more vigorously $(\mathrm{p}<0.05)$. In the opinion of the respondents, higher proportion of female students preferred first child to be male while male students showed a preference for female as first child $(p<0.05)$. Son preference was the main possible reason for female foeticide and creating more awareness in society about PCPNDT Act was the need of the hour to improve declining sex ratio according to respondents $(\mathrm{p}<0.05)$ (Table 3).

\section{DISCUSSION}

The discrimination against girl child begins in the womb as the unborn girl child faces the peril of pre-birth elimination due to newer technology available since last few decades.

$80 \%$ of the medical students in the present study were aware of the declining sex ratio in India and awareness was higher among females. In other studies, conducted by Patil S et al and Sidhu TK et al, $98 \%$ of the medical graduates had heard of female foeticide. ${ }^{8,9}$ However in contrast, Palo LB et a $1^{10}$ reported lower rate of awareness about declining sex ratio $(45.3 \%)$ though the awareness levels were higher among males than females. Avachat $S$ et al from Maharashtra in a study reported $41.9 \%$ and $25.7 \%$ awareness levels among male and female interns about declining sex ratio. ${ }^{11}$ Since the medical students in the present study were just first year MBBS students, higher awareness levels in them is highly commendable. 
Table 3: Attitude of the respondents towards the PCPNDT act $(n=140)$.

\begin{tabular}{|c|c|c|c|c|c|}
\hline Question & Response & Male $(n=67)$ & Female $(n=73)$ & Total $(n=140)$ & P value \\
\hline \multirow{2}{*}{$\begin{array}{l}\text { Should sex determination be } \\
\text { punished more vigorously }\end{array}$} & Yes & $54(80.59)$ & $68(93.15)$ & $122(87.14)$ & \multirow{2}{*}{0.02} \\
\hline & No & $13(19.40)$ & $5(6.85)$ & $18(12.86)$ & \\
\hline \multirow{2}{*}{$\begin{array}{l}\text { In your opinion, what should be the } \\
\text { preferred birth order of first child }\end{array}$} & Male child & $30(44.78)$ & $48(65.75)$ & & \multirow{2}{*}{0.01} \\
\hline & Female child & $37(55.22)$ & $25(34.25)$ & & \\
\hline \multirow{4}{*}{$\begin{array}{l}\text { In your opinion, what are possible } \\
\text { reasons for female foeticide* }\end{array}$} & Son preference & $49(73.13)$ & 67 (91.78) & $116(82.85)$ & \multirow{4}{*}{0.28} \\
\hline & Dowry & $33(49.25)$ & $42(57.53)$ & 75 (53.57) & \\
\hline & $\begin{array}{l}\text { Gender } \\
\text { inequality }\end{array}$ & $37(55.22)$ & $36(49.31)$ & $73(52.14)$ & \\
\hline & $\begin{array}{l}\text { Marriage } \\
\text { problem of } \\
\text { females }\end{array}$ & $26(38.80)$ & $19(26.02)$ & $45(32.14)$ & \\
\hline \multirow{4}{*}{$\begin{array}{l}\text { In your opinion, what impact the } \\
\text { female foeticide has on society }\end{array}$} & $\begin{array}{l}\text { Adverse effects } \\
\text { on health }\end{array}$ & $28(41.79)$ & 25 (34.24) & $53(37.85)$ & \multirow{4}{*}{0.30} \\
\hline & $\begin{array}{l}\text { Increase sexual } \\
\text { and social crime } \\
\text { on women }\end{array}$ & 45 (67.16) & $56(76.71)$ & $101(72.14)$ & \\
\hline & $\begin{array}{l}\text { Increase } \\
\text { prostitution, } \\
\text { sexual } \\
\text { exploitation, } \\
\text { increase } \\
\text { HIV/AIDS }\end{array}$ & 28 (41.79) & $48(65.75)$ & $76(54.28)$ & \\
\hline & Any other & $05(7.46)$ & 09 (12.32) & $14(10.00)$ & \\
\hline \multirow{4}{*}{$\begin{array}{l}\text { In your opinion, what need to be } \\
\text { done to improve sex ratio* }\end{array}$} & $\begin{array}{l}\text { Strict } \\
\text { implementation } \\
\text { of act }\end{array}$ & $38(56.71)$ & $37(50.68)$ & $75(53.57)$ & \multirow{4}{*}{0.59} \\
\hline & $\begin{array}{l}\text { Enhancing } \\
\text { punishment }\end{array}$ & $34(50.74)$ & $36(49.31)$ & $70(50.00)$ & \\
\hline & $\begin{array}{l}\text { Creating more } \\
\text { awareness }\end{array}$ & 41 (61.19) & $59(80.82)$ & $100(71.42)$ & \\
\hline & Any other & $06(8.95)$ & 08 (10.95) & $14(10.00)$ & \\
\hline
\end{tabular}

Main source of information regarding declining sex ratio among respondents in the current study was mass media which was in agreement with the results reported by Patil $S$ et al while internet was the main source of information for $44 \%$ respondents in a study by Palo LB et al. ${ }^{8,10}$ Only $24.29 \%$ of the students had heard of PC-PNDT Act out of which three fourth were able to write its full name. Patil S et al reported that more than $3 / 4^{\text {th }}$ of respondents knew about the act but only $61 \%$ could write its full name. ${ }^{8}$ $74.7 \%$ students were aware of PC-PNDT Act in a study by Palo LB et al while Sidhu TK et al reported that $56.5 \%$ students had heard of PC-PNDT Act. ${ }^{10,9}$ Regarding prenatal sex determination a punishable offence, a whopping $95 \%$ were aware of this fact in the present study and more than three fourth amongst them were aware that both fine as well as imprisonment as punishment under the act. Palo LB et al reported that $73.3 \%$ of the participants knew that prenatal sex determination was a punishable offence and $56 \%$ of them responded correctly about the punishment (fine and imprisonment both). ${ }^{10}$ Patil $\mathrm{S}$ et al also reported results which concur with the results of the present study. ${ }^{8}$ Sidhu
TK et al reported that $63 \%$ of medical undergraduates knew that both fine and imprisonment are the penalties under the act. ${ }^{9}$ Regarding technique for prenatal sex determination, $50 \%$ respondents were aware of ultrasonography followed by $44 \%$ by amniocentsis. Since USG is the main technique for prenatal sex determination, authors presume that those medical students not knowing of any technique may have opted for amniocentesis. That is probably the reason for higher response for amniocentesis. Patil $\mathrm{S}$ et al in their study observed that about two third of respondents were aware of ultrasonography as tool for sex determination. ${ }^{8}$ Awareness about USG machine registration was higher in the present study in comparison to the study conducted by Patil S et al $(92 \%$ vs $86 \%){ }^{8}$ Also awareness about persons to be held responsible for sex determination under the PC-PNDT Act was in agreement with results reported by Dhaduk KM et al. ${ }^{12}$ In contrast Patil $\mathrm{S}$ et al reported lower levels of awareness (59\%) among respondents on this count. ${ }^{8} 87.14 \%$ of the respondents in the present study were of the opinion that sex determination be punished more vigorously which concur 
with the results reported by Palo LB et al but were in total contrast to the results reported by Nath A et al where less than one third of the participants were in favour of stricter punishment for doctors involved in the practice. ${ }^{10,13}$

Regarding impact of female foeticide on society, $72 \%$ reported that it would increase sexual and social crime on women and similar proportion reported in a study by Patil $S$ et al that it would have adverse effects on female health (physical and mental). ${ }^{8} 71 \%$ of the respondents reported that creating more awareness about PC-PNDT Act was needed to improve sex ratio which was similar to those reported by Avacaht $\mathrm{S}$ et al. ${ }^{11}$ Attitude among the female respondents for higher preference of male first child reflects that son preference is still ingrained in the psyche of even new generation Indian females. It can be best described in the context of typical Indian traditions and century old beliefs of a male being a heir as well as dire necessity for last rites in the family. The trends show that though there may be some change in the outlook towards girl child but there has not been any paradigm shift. Since the present study was conducted among the first-year medical undergraduates, there were certain deficiencies regarding awareness of various aspects of PCPNDT Act and it is hoped that as they advance towards final year MBBS/ Internship, they would be fully converse with all the parameters of PCPNDT Act. Authors further recommend that PCPNDT Act should be discussed in detail with medical graduates especially by faculty of community medicine. The medical council of India has laid stress on the fact to educate doctors about humanities from the beginning of their medical career so that they are sensitized towards social and ethical issues.

\section{CONCLUSION}

Majority of respondents were aware regarding sex determination during pregnancy and declining sex ratio, although only one third of them were aware about PCPNDT Act. Female respondents of the current generation have shown more preference for a first birth male child which is a cause of concern. Regular workshops and continuing medical education (CME) sessions need to be held to update their knowledge on a regular basis. Sensitising future doctors about the ethics related to the inappropriate and indiscriminate use of technology could go a long way in curbing this social evil in India.

Funding: No funding sources

Conflict of interest: None declared

Ethical approval: The study was approved by the Institutional Ethics Committee

\section{REFERENCES}

1. Definition of the indicators of population ageing. World Population ageing 1950- 2050. UNFPA. Available from:

http://www.un.org/esa/population/publications/worldag eing19502050/pdf/95annexi.pdf. Accessed 7 April 2017

2. Census of India. Gender composition 2011. Available from:

http://censusindia.gov.in/Census_And_You/gender_co mposition.aspx. Accessed 7 April 2017

3. Census of India. Sex composition of India. Available from:

http://censusindia.gov.in/Data_Products/Library/Provisi onal_PopulationTotal_link/PDF_Links/chapter6.pdf.

4. Kanitkar T, Mistry M. Status of women in India - an interstate comparison. Indian J Soc Work. 2000;61:3813.

5. Imam Z. India bans female feticide. BMJ. 1994;309:428.

6. Handbook of PCPNDT Act and rules with amendments. Ministry of Health and Family Welfare Government of India 2006. Available from: http://www.iria.in/uploadNotices/Handbook_on_PNDT _Act.pdf.

7. Declining sex ratio-a matter of concern- India. UNICEF. Available from http://www.unicef.org/india/child_protection_1360.htm.

8. Patil S, Singh V, Chavan S, Gadkari M. Knowledge and attitude regarding PCPNDT act among medical undergraduates: a study conducted in teaching institute Mumbai. Innovative J Medic Health Sci. 2014:4(2);835 .

9. Sidhu TK, Kumar S, Kaur PA. Study of knowledge and attitude of medical undergraduate students regarding prenatal sex determination and female feticide. Indian J Matern Child Health. 2011;13:2-6.

10. Palo LB, Chauhan NS, Parvathi T, Chauhan RC. Awareness about PCPNDT act among undergraduate students of a medical college in Puducherry. Int $\mathrm{J}$ Reprod Contracept Obstet Gynecol 2015;4:1485-8.

11. Avachat S, Raut P, Zambare M, Gund D, Pundkar R. Perspectives of medical interns regarding female feticide and declining sex ratio in India. N Am J Med Sci. 2013;5(8):469-72.

12. KM Dhaduk. A study on doctor's perspective on PNDT Act. Ind J Community Medic. 2009;34(2):160-1.

13. Nath A, Sharma N, Knowledge and attitudes of medical students and interns with regard to female feticide, Indian J Comm Medic. 2009;34:164.

Cite this article as: Gupta RK, Singh P, Hussain S, Kumari R, Langer B, Gupta R. PC-PNDT act: perspectives of medical undergraduates in a SubHimalayan state. Int J Reprod Contracept Obstet Gynecol 2017;6:3545-9. 